The International Journal of Indian Psychology

ISSN 2348-5396 (e) | ISSN: 2349-3429 (p)

Volume 4, Issue 1, No. 69, DIP: 18.01.016/20160401

ISBN: 978-1-365-45447-9

http://www.ijip.in | October-December, 2016

\title{
A Study on Occupational Stress among BPO Workers
}

\author{
Dr. Santosh $\operatorname{Kumar}^{1} *$
}

\section{ABSTRACT}

The current study reveals that occupational stress among BPO Workers the study says that BPO Workers person they have moderate occupational stress, there is no significant difference in occupational stress among male and female BPO Workers.

Keywords: Occupational Stress, BPO Workers

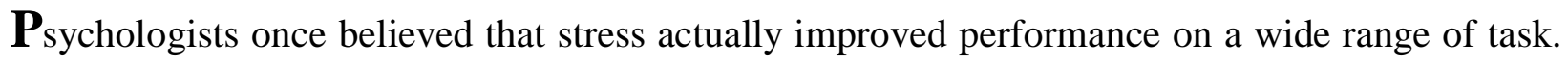
They held that the relationship between stress and task performance takes the form of an upside down is at first performance improves as stress increase presumably because the stress is arousing or energizing Beyond some point though stress becomes distracting and performance actually drops.

While this relationship may hold true under some condition growing evidence suggest that even low or moderate level of stress com interfere with task performance (motowidlo Packard \& manning 1986 stress 1984).

It is clear that individual differ in their resistance to stress. Some people seem to be disease prone. They suffer ill effect from even mild level of stress other people sometimes referred to as self headers are able to function effectively even in the face of intense ongoing stress (fried man).

According to Beer and Newman define job stress as a condition arising from the interactive of people and their job and characterized by changes within people that force them to deviate from their normal functioning.

1) Stress is not simply anxiety: Anxiety operates solely in the emotional and psychological sphere whereas stress operates there and also in the physiological sphere.

\footnotetext{
${ }^{1}$ Asst. Professor, Maharanis Arts, Commerce and Management College For Woman. Bangalore, India *Responding Author

(C) 2016, S Kumar; licensee IJIP. This is an Open Access Research distributed under the terms of the Creative Commons Attribution License (http://creativecommons.org/licenses/by/2.0), which permits unrestricted use, distribution, and reproduction in any Medium, provided the original work is properly cited.
} 


\section{A Study on Occupational Stress among BPO Workers}

2) Stress is not simply neNous tension: Like anxiety neNous tension may result from stress but the two is not the same unconscious people have exhibited stress and some people may keep it butted up and not revered it through neNous tension.

3) Stress is not necessarily something damaging: Bad or to be avoided esters is not damaging or bad and is something people should seek out rather than avoided.

Rapid pulse1 pounding heart; increased perspiration1 testing 8f arm and leg muscles) shortness of breath gritting of teeth. 3ehavioral to stress are deterioration in performance restiveness smoking and use of alcohol or other recreational drugs accident proneness neNous mannerism (food taping nail biting) increased or decreased editing increased or decreased sleeping.

\section{Conceptual Framework}

Stress

Stress is a dynamic condition in which an individual is confronted with an opportunity constraint or demand related to what he or she desires and for which the outcomes is perceived to be both uncertain and important.

Stress is not necessarily bad in and of itself while stress is typically discussed in a negative content it also has positive value. It is an opportunity when it offers potential gain.

\section{Types of Stress}

The major types of stress can be broken down into four different categories eustress Hyper stress, hypo stress \& Distress.

\section{1) Eustress}

It is the type of stress you experience right before you have the need to exert physical force eustress prepares the muscles heart and mind for the strength needed for whatever is about to occur. Eustress can also apply to creative endeavors when a person need to have some extra energy eustress kicks in to bring them the inspiration they need.

An athlete will experience the strength that comes form eustress right before they play a big game or enter competition. because of the eustress they immediately receive the strength that they need to perform. When they body enters the fight or fight response. It will experience eustress the eustress prepare the body to fight with or free from on imposing danger. This type of stress will cause the blood to pump to the major muscles group and will increase the heart rate and blood pressure to increase. If the event danger passes. The body will eventually return to its normal state. 


\section{A Study on Occupational Stress among BPO Workers}

\section{2) Distress}

Distress is one of the negative types of stress. This is one of the types of stress that the mind and body undergoes when the normal routine is constantly adjusted and attired. The mind is not comfortable with this routine and craves the familiarity with this routine. There are actually two types of distress.
a) Acute Stress
b) Chronic Stress

\section{a) Acute Stress}

Acute stress is usually for short time and may be due to work pressure meeting deadlines pressure or minor accident over exertion increased physical activity searching something but you misplaced it or similar things.

Symptoms: Of this types of tension are headaches back pain, stomach problem rapid heartbeat muscle aches or body pain acute stress is common in people who take too many responsibilities and are overload disorganized always in a hurry and never $\mathrm{n} \mathrm{km}$ time. These people are generally in positions of important at their work place and stressful life style is inherent in them symptoms of this type of stress are prolonged tension headaches hypertension migraines chest pain and heart disease.

\section{2) Chronic Stress}

Chronic stress will occur if there is a constant change of routine of routine for week months. Chronic stress affects the body for a long period of time. This stress is due to poverty broken or stressed families and marriages chronic illness and successive failures in life people suffering from this type of stress get used to it and may even not realize that they are under chronic stress. It is very harmful to their health.

\section{Physical and Mental Signs of Short Term and Long Term Stress}

Often occurring in quick bursts in reactions to something in your environment short term stress cam affects your body in many days.

- Making your heart-beat and breath faster.

- Making you sweat more

- Leaving you with cold hands feet or skin

- Making you feel sick to your stomach or giving you butterflies.

- Tightening your muscles or making you feel tense.

- Leaving your mouth dry.

- Making you have to go to the bathroom frequently

- Increasing muscles spasms headaches fatigue and shortness of breath.

While this burst of energy may help you in physical situation where your body needs to react quickly. It cam have bad effects on your mind and performance. If there is no outlet reason for your stress.

(C) The International Journal of Indian Psychology, ISSN 2348-5396 (e)| ISSN: 2349-3429 (p) | 130 


\section{A Study on Occupational Stress among BPO Workers}

Changing your sleep habits: (Either causing you to sleep too much or not letting you sleep enough)

Physical conditions

- Hypertension.

- Heart disease

- Strokes

- Diabetes

- Ulcers

- Infection diseases

- Spastic celon

Psychological problem

- Serious depression

- Accidents

- Domestic violence

- $\quad$ suicidal behaviors

- alcoholism

- senous substance abuse

- Other debilitating psychological disorder.

1) Causes of stress

- Death of spouse family near relative or friend

- Injury or illness of any family member

- Marriage of self or son or daughter of brother or sister etc.,

\section{Occupational Stress}

Stress can be defined as an adverse reaction people have to excessive pressure or other type of demand placed upon them more than half a million people currently report experiencing stress associated with work at a level which makes them will.

The employer has an important role in controlling work place factors which have been shown to be associated with work related stress and encouraging employees to report concerns at an early stage and identify appropriate support whilst the employer is not under a legal duty to prevent non-work factors a supportive environment will help employees to seek help for other issues and minimize their impact at work.

No common trend in claims arising from occupational stress developed until the case of Halton in 2002. it was decided that it was necessary to return to the basic duty care.

- The halton guidance can basically be reduced

- The employer must be able to reasonably foresee the injury.

before a duty of care arises. An employer can normally assume that the employer is able to cope with the normal pressures associated with work. 


\section{A Study on Occupational Stress among BPO Workers}

\section{Potential sources of stress}

There are three categories of potential stress environmental, organizational and individual.

Environmental factor: Just as environmental uncertainty influences the design of an organizations structure it also influences stress level among employees that organization. Changes in the business cycle create economic uncertainties when the economy is contracting.

For e.g. people become increasingly anxious about their security political uncertainties don't tend to create stress among North American as they do for employees in countries like irad.

Technological uncertainty is a Third of environmental factor that can cause stress. Because new innovations can make and employee's skill and experience obsolete in a very short period of time computers robotics automation and similar forms of technological innovation are a threat to on any people and case them stress.

Organization factors: There is no shortages of factors within the organization that can cause stress pressures to avoid errors or coraplete asks in a limited time period work overload a demanding and insensitive boss and unpleasant co-workers a we've categorized these factors around task role and interpersonal demands organizational structure organizational leadership and the organizations life stage.

\section{BPO Workers}

It has long been assumed that BPO Workers work is the world's most stressful occupation, but comparative studies of occupational stress have revealed that correctional work such as business emergency medical services and correctional work are more stressful them policing (Patterson 1992).

The symptoms of BPO Workers stress may be difference however for one thing the effects are usually delayed more closely resembling the symptoms of PTSDC post teammates stress director) or bar out (sometimes called cumulative stress reduction but bar out a disease of over commitment is the more reversible condition characterized more by temper Flare ups)

The symptoms appear one day from out of the blue in officers who have not shown even the slightest early warning sign research has shown that officers with five to ten year of service usually have the highest means stressor scoren (Violanti Aron 1995).

\section{1) Suicide}

BPO Workers officer kill themselves at the rate six greater then in the general population and BPO Workers officer kill themselves at a rate 8.3 times greater than those who die at the hands criminals (violanti 1996) Although you often don't seen it coming and there usually no history of 


\section{A Study on Occupational Stress among BPO Workers}

counseling before and BPO Workers suicides via psychological autopsies have been linked to diagnosable mental disorder most often involving depression alcohol or drug abuse.

\section{2) Alcohol}

The rates are high possibly because of the stigma associated with illegal drugs older officer highest rate and there is significant female and minority involvement several studies conducted in the 1970 locked at drinking on duty as an indicator of alcoholism and produced some frightening figures from reiss $25 \%$ to van raolte $67 \%$ other studies have looked at the cup ulcer rate estimate at $30 \%$ and fifteen and dietary of officers more recent studies have looked at drug are and abuse.

\section{REVIEW OF LITERATURE}

Ernakulam District of Keral Beehr and Newman (1978) define occupational stress as "A condition arising from the interaction of people and their jobs and characterized by changes within people that force them to deviate from their normal functioning" $\mathbf{C o b b}(\mathbf{l}$ 975) has the opinion that "The responsibility load creates server stress among workers and manager cannot cope with the increased responsibilities it may lead to several physical and psychological disorders among them". Brook (1973) reported that quality live changes in the job create adjust mental problem among employees. The intrapersonal relationships within the departmental and between the departments create qualitative difficulties within the organization to a great extend. According to French \& Caplan (1975) pressure of both qualitative and quantitative overload can result in the need to work. Excessive hours which is an additional source of stress "Having to work under time pressure in order to meet deadlines is ana independent source of stress studies shows that stress levels increase as difficult deadlines draw near”.) The study of Michal Mermot (1990 University of London U.K.) say that individual perception also plays a role in occupational stress that difference employees perceive and react differently in given situation of work environment some with high stress level and some with low or even do not. Copper and Marchal (1976) states that occupational stress included the invironmental factor or stressor such as work overload role ambiguity role conflict and poor working condition associated with a particular job.

\section{METHODOLOGY}

In the present study consist of 50 BPO Workers person from different BPO Workers station in Gulbarga city. The name of this BPO Workers station is Brahmpur BPO Workers, Mahila BPO Workers Station, Ashok Nagar BPO Workers Station, and Station Bazar BPO Workers Station. Problem: To study the occupational stress among BPO Workers (Male/Female)

\section{Variable}

l) Independent variable: Gender

2) Dependent variable: Occupation stress 


\section{A Study on Occupational Stress among BPO Workers}

\section{Objective}

l) To know the level of occupational stress among BPO Workers.

2) To know the difference in occupational stress among male and female BPO Workers.

\section{Hypothesis}

l) BPO Workers personal have high occupational stress

2) Female BPO Workers in having more occupational Stress then male BPO Workers Personnel

\section{Sample design:}

The sample for the present study comprises 50 BPO Workers randomly selected from different BPO Workers station in Gulbarga City.

\begin{tabular}{|l|l|}
\hline Male & 25 \\
\hline Female & 25 \\
\hline Total & 500 \\
\hline
\end{tabular}

\section{Tool:}

In the present study the occupational stress questionnaire (O.S.Q.) developed by Dr. S.K. Srivastava and Dr. A. P. Singh is used scale consists of 46 items each to be noted on the five point scale out of 46 items 28 are true keyed and rest 18 are false keyed.

\begin{tabular}{|l|c|c|}
\hline \multirow{2}{*}{$\begin{array}{l}\text { Categories of } \\
\text { response }\end{array}$} & $\begin{array}{c}|c| \\
\text { True-keys } \\
\text { Items }\end{array}$ & $\begin{array}{c}\text { False keyed } \\
\text { Items }\end{array}$ \\
\cline { 2 - 3 } $\begin{array}{l}\text { Never /strongly } \\
\text { disagree }\end{array}$ & 1 & 5 \\
\hline Seldon I disagree & 2 & 4 \\
\hline Sometimes/Undecided & 3 & 3 \\
\hline Mostly I Agree & 4 & 2 \\
\hline $\begin{array}{l}\text { Always /Strongly } \\
\text { agree }\end{array}$ & 5 & 1 \\
\hline
\end{tabular}

If the score is between 46 to 127 low occupational stresses 128 to 150 moderate occupational stresses and 151 to 230 high Occupational stress.

\section{Statistical Analysis:}

Mean S.D. t. value is calculated for Interpretation of result.

\section{DISCUSSION}

Stress is usually through of in negative term. It is through to be caused by something bad. For e.g. A College student is placed on scholastic probation a loved one is seriously ill or the boss 


\section{A Study on Occupational Stress among BPO Workers}

give a formed repairman for poor. This is a form of distress but there is positive pleasant side of stress caused by good things.

Stress contributed not only to the physical disorder previously mentioned but also to emotional problem some research suggest that BPO Workers commit suicide at a higher rate than other groups.

Table showing mean S.D and t. value of occupational stress among BPO Workers (Male/Female)

\begin{tabular}{|l|l|l|}
\hline & Male & Female \\
\hline Mean & 144 & 148.8 \\
\hline SD & 11.8 & 12.6 \\
\hline \multicolumn{3}{|c|}{ t-value } \\
\hline
\end{tabular}

Table showing the means S.D and t-value of the occupational stress among BPO Workers (male and female). The mean value of the male and female are different. i.e the Mean value of male is"l 44 " where as the mean value of Female is " 148.8". There is difference in the occupational stress among male and Female. The female BPO Workers have more occupational stress than the male BPO Workers.

The S.D of male is 11.18 and that of Female is 12.6 which is slight greater than male. When test was applied to test the significant different in occupational stress, it was found that calculated ' $t$ ' value indicate that both male \& Female BPO Workers are having moderate occupational stress.

\section{CONCLUSION}

1. BPO workers persons are having moderate occupational stress

2. There is no significant difference in occupational stress among male and female BPO workers.

\section{Acknowledgments}

The author appreciates all those who participated in the study and helped to facilitate the research process.

\section{Conflict of Interests}

The author declared no conflict of interests.

\section{REFERENCES}

D.M. Pestonji: Stress and Coping Sage Publication. New Delhi. Second Edition -1999

F. Luthans (1989) Organizational Behaviour, Indian Journal Of Psychology 2005 (1)

K Anand, Y Nagle (2016), Perceived Stress as Predictor of Psychological Well-being among Indian Youth, International Journal of Indian Psychology, Volume 3, Issue 4, No. 68,

(C) The International Journal of Indian Psychology, ISSN 2348-5396 (e)| ISSN: 2349-3429 (p) | 135 


\section{A Study on Occupational Stress among BPO Workers}

ISSN:2348-5396 (e), ISSN:2349-3429 (p), DIP:18.01.213/20160304, ISBN:978-1-36539398-3

Kaplan H.L And Sadock B.J. (1991) Synopsis Of Psychiatry Sixth Edition Willams And Wilkins Kumar, P Middha (2016), The Role of Educator \& Parents In Management of Academic \& Examination Stress of Student's, International Journal of Indian Psychology, Volume 3, Issue 4, No. 68, ISSN:2348-5396 (e), ISSN:2349-3429 (p), DIP:18.01.215/20160304, ISBN:978-1-365-39398-3

Luthan Fried (1988) Organizational Behaviour. New York. Mcgraw-Hill Publication.

N Mutalik, S Moni, S Choudhari, G Bhogale (2016), Depression, Anxiety, Stress among College Students in Bagalkot: A College Based Study, International Journal of Indian Psychology, Volume 3, Issue 4, No. 68, ISSN:2348-5396 (e), ISSN:2349-3429 (p), DIP:18.01.210/20160304, ISBN:978-1-365-39398-3

How to cite this article: S Kumar (2016), A Study on Occupational Stress among BPO Workers, International Journal of Indian Psychology, Volume 4, Issue 1, No. 69, ISSN:23485396 (e), ISSN:2349-3429 (p), DIP:18.01.016/20160401, ISBN:978-1-365-45447-9 